\title{
Preface to the English edition
}

The cult of Mithras has fascinated ancient historians for a century now, thanks chiefly to Franz Cumont's indefatigable energy in collecting and interpreting the texts and monuments. One cannot of course today accept all his views and constructions - some of them indeed seem to me quite wrong. But in general, all criticism of details aside, his work calls to mind Friedrich Nietzsche's remark, 'We should honour the errors of the great: they are more fertile than the truths of lesser men.' Students of Mithraism, myself included, owe an enormous debt to critical engagement with Cumont's views.

My interest in the study of Mithras as the focus of a Roman mystery cult now goes back a decade and a half. Alongside an analysis of the social composition of almost 500 small, sometimes tiny, Mithraic congregations in the Roman empire, I published some while ago a general interpretation of the cult, drawing upon all the wide range of literary, epigraphic and archaeological evidence. It is an honour to have it now translated into English. For this edition, the basic structure has not been altered, but in some places I have taken note, at least briefly, of important new finds and discussions, and included references to them in the notes. The notes themselves are intended primarily to provide references for statements in the text, but the further literature cited in them should also enable the interested reader to follow up questions that could not fully be dealt with given the scope of the book. It may indeed be that, despite all one's efforts, much still remains opaque. But, in studying what is after all a mystery-cult, should we really expect anything else?

The book has found an ideal translator in Richard Gordon. I would like to thank him warmly for the patience and the intelligence he has brought to the task. I am also grateful to him for supplying many references and corrections of slips and errors. My further thanks are due to John Davey for arranging for the English translation. 
